\title{
Analisis Persepsi Masyarakat terhadap Bank Syariah \\ di Kabupaten Polewali Mandar Sulawesi Barat
}

\author{
Sri Astuty Ratnasari Manggu ${ }^{1}$ dan $^{\text {Dalif }}{ }^{2}$ \\ ${ }^{1}$ Program Studi Akuntansi Fakultas Ekonomi Universitas Sulawesi Barat \\ ${ }^{2}$ Universitas Sulawesi Barat \\ email: sriastutyrm@gmail.com
}

\begin{abstract}
ABSTRAK
Penelitian ini bertujuan untuk mengetahui persepsi masyarakat terhadap bank syariah serta pengaruh persepsi atas perbankan syariah tersebut terhadap preferensi masyarakat pada bank syariah di Kabupaten Polewali Mandar Sulawesi Barat. Metode pengumpulan data dilakukan dengan penarikan sampel dari populasi dengan sistem cluster : yaitu nasabah bank konvensional, nasabah bank syariah, nasabah bank syariah dan konvensional, dan masyarakat umum yang ada di Kota Polewali dan Wonomulyo. Teknik pengumpulan datanya melalui kuisioner, sedangkan analisis data dengan analisis deskriptif dan analisis regresi linier sederhana. Hasil penelitian menunjukkan bahwa dari sisi persepsi, sebagian besar masyarakat menyetujui keberadaan bank syariah yang menerapkan prinsip bagi hasil yang sesuai dengan syariat Islam serta keberadaan bank syariah yang berbeda dari sistem perbankan konvensional. Akan tetapi masih terdapat keragu-raguan/sikap netral dari masyarakat terhadap pemahaman akan riba yang difatwakan haram oleh Majelis Ulama Indonesia (MUI) serta sistem bunga yang termasuk kategori riba yang dijalankan oleh perbankan konvensional. Dari sisi preferensi masyarakat terhadap bank syariah, sebagian besar masyarakat berdasarkan hasil kuisioner belum sepenuhnya menempatkan pilihannya pada perbankan syariah. Hal ini secara umum menunjukkan bahwa walaupun masyarakat telah mengakui keberadaan perbankan syariah, akan tetapi tidak serta merta hal tersebut mendorong masyarakat untuk memilih bank syariah. Sementara itu berdasarkan hasil pengujian hipotesis yang telah dilakukan, diperoleh hasil bahwa persepsi masyarakat terhadap bank syariah berpengaruh secara positif dan signifikan terhadap preferensi masyarakat pada bank syariah.
\end{abstract}

Kata Kunci: persepsi, preferensi masyarakat, bank syariah

\section{PENDAHULUAN}

\subsection{Latar Belakang}

Peran Perbankan Syariah sebagai alternatif lembaga keuangan bagi masyarakat saat ini semakin berkembang. Kebutuhan akan produk-produk syariah yang diberikan oleh lembaga keuangan yang menjalankan aktivitasnya sesuai dengan prinsip-prinsip syariah menjadi sebuah kebutuhan yang perlu direspon dengan baik oleh perbankan syariah. Menurut data statistik perbankan syariah yang dikeluarkan oleh Bank Indonesia menunjukkan bahwa saat ini telah ada 6 bank umum syariah dan 25 unit usaha syariah yang dimiliki oleh bank umum konvensional serta 138 bank pembiayaan rakyat syariah di Indonesia. Potensi pengembangan perbankan syariah cukup besar mengingat bahwa sebagian besar masyarakat di Indonesia beragama Islam.

Namun di sisi lain, potensi dan peran perbankan syariah tersebut belum diikuti dengan peningkatan pangsa pasar bank syariah dibandingakan dengan bank konvensional. Menurut Otoritas Jasa Keuangan (OJK), pangsa pasar (market share) bank syariah terhadap total pasar perbankan nasional baru mencapai $4,87 \%$ pada akhir tahun 2015 atau masih di bawah target minimal 5\%. Kurangnya minat masyarakat terhadap perbankan syariah disebabkan oleh banyak faktor. Salah satu faktor adalah kurangnya pengetahuan dan pemahaman serta persepsi masyarakat yang umumnya masih keliru atau tidak tepat terhadap bank syariah.

Menurut Undang-undang Nomor 10 tahun 1998 Bank Syariah adalah Bank Umum yang melaksanakan kegiatan usaha berdasarkan prinsip syariah yang dalam kegiatannya memberikan jasa dalam lalu lintas pembayaran. Sedangkan menurut Undang-undang Nomor 21 Tahun 2008, Bank Syariah adalah bank yang menjalankan kegiatan usahanya berdasarkan prinsip syariah dan menurut 
jenisnya terdiri atas Bank Umum Syariah dan Bank Pembiayaan Rakyat Syariah. Prinsip syariah adalah prinsip hukum Islam dalam kegiatan perbankan berdasarkan fatwa yang dikeluarkan oleh lembaga yang memiliki kewenangan dalam penetapan fatwa di bidang syariah. Pembiayaan berdasarkan prinsip syariah adalah penyediaan uang atau tagihan yang dipersamakan dengan itu berdasarkan dengan persetujuan atau kesepakatan antara Bank dengan pihak lain yang mewajibkan pihak yang dibiayai untuk mengembalikan uang atau tagihan tersebut setelah jangka waktu tertentu dengan imbalan atau bagi hasil. Muhammad (2002) menyimpulkan "Bank Syariah adalah lembaga keuangan yang usaha pokoknya memberikan pembiayaan dan jasa-jasa lainnya dalam lalu lintas pembayaran serta peredaran uang yang pengoperasiannya disesuaikan dengan prinsip syariat Islam".

Bank Syariah dengan bank konvensional memiliki beberapa perbedaan di antaranya yaitu:

Tabel 1. Perbedaan Bank Syariah dengan Bank Komvensional

\begin{tabular}{|c|c|c|}
\hline Jenis perbedaan & Bank syariah & Bank konvensional \\
\hline Landasan hukum & Al Qur`an \& as Sunnah + Hukum positif & Hukum positif \\
\hline Basis operasional & Bagi hasil & Bunga \\
\hline Skema produk & $\begin{array}{l}\text { Berdasarkan syariah, semisal } \\
\text { mudharabah, wadiah, murabahah, } \\
\text { musyarakah dan sebagainya }\end{array}$ & Bunga \\
\hline Perlakuan terhadap & Dana masyarakat merupakan & Dana masyarakat \\
\hline Dana Masyarakat & $\begin{array}{l}\text { titipan/investasi yang baru mendapatkan } \\
\text { hasil bila di'usahakan' terlebih dahulu }\end{array}$ & $\begin{array}{l}\text { merupakan simpanan } \\
\text { yang harus dibayar } \\
\text { bunganya saat jatuh } \\
\text { tempo }\end{array}$ \\
\hline Landasan hukum & Al Qur`an \& as Sunnah+Hukum positif & Hukum positif \\
\hline Sektor penyaluran dana & Harus yang halal & $\begin{array}{l}\text { Tidak memperhatikan } \\
\text { halal/haram }\end{array}$ \\
\hline Organisasi & $\begin{array}{l}\text { Harus ada DPS (Dewan Pengawas } \\
\text { Syariah) }\end{array}$ & Tidak ada DPS \\
\hline
\end{tabular}

Sumber: www.syariahmandiri.co.id

Menurut Webster sebagaimana dikutip oleh Sutisna (2001), menyatakan persepsi adalah proses bagaimana stimulus-stimulus yang mempengaruhi tanggapan-tanggapan itu diseleksi dan diinterpretasikan. Stimulus adalah setiap bentuk fisik atau komunikasi verbal yang dapat mempengaruhi tanggapan individu. Salah satu stimulus yang penting yang dapat mempengaruhi perilaku konsumen adalah lingkungan (sosial dan budaya). karena persepsi setiap orang terhadap suatu objek akan berbeda-bada, oleh karena itu persepsi mempunyai sifat subjektif. Persepsi seorang konsumen akan berbagai stimulus yang diterimanya di pengaruhi oleh karakteristik yang dimilikinya. Sementara itu, Dalam Kamus Lengkap (2007), disebutkan bahwa preferensi adalah hak (untuk) didahulukan dan diutamakan, diprioritaskan, pilihan kecenderungan atau kesukaan dalam menggunakan atau memanfaatkan suatu barang atau jasa. Preferensi adalah kecenderungan seseorang dalam memilih suatu produk yang didasarkan atas keinginan, kepentingan, dan seleranya. Dimana dalam hal ini seorang konsumen diharapkan mampu membedakan setiap produk yang akan dihadapinya, serta membuat daftar preferensinya (rank preference) atas seluruh produk tersebut. Preferensi konsumen bersifat subyektif, dimana preferensi antara konsumen satu dengan yang lainnya tidaklah sama. Ketidaksamaan ini disebabkan oleh perbedaan kepentingan dikarenakan banyak faktor.

Dari hasil penelitian yang dilakukan oleh Lailatus Sembrada (2015) tentang persepsi, perilaku dan preferensi masyarakat Tulungagung terhadap Bank Muamalat, menunjukkan bahwa persepsi masyarakat Tulungagung terhadap Bank Muamalat Indonesia KCP Tulungagung adalah baik akan tetapi di sisi lain preferensi masyarakat Tulungagung terhadap Bank Muamalat Indonesia KCP Tulungagung masih rendah. Berdasarkan beberapa penelitian di atas menunjukkan bahwa struktur pemahaman dan persepsi masyarakat yang sudah terbangun sekian lama terhadap bank konvesional tentu saja tidak mudah untuk diarahkan kepada perbankan yang berasaskan syariah Islam, terutama terkait persepsi masyarakat yang masih salah tentang perbankan syariah dan mengarah kepada preferensi masyarakat yang masih rendah kepada bank syariah. Saat ini di kabupaten Polewali Mandar, khususnya di kota Polewali dan Wonomulyo telah berdiri 4 Bank Syariah, yaitu Bank Syariah Mandiri (BSM), Bank Muamalat Cabang Polewali, Bank Muamalat Cabang Wonomulyo, dan BNI Syariah KCP Mikro Wonomulyo. Perkembangan bank syariah di Kabupaten Polewali tersebut masih cukup rendah. 


\subsection{Rumusan Masalah}

Berdasarkan uraian yang dipaparkan pada latar belakang tersebut di atas, maka yang menjadi rumusan masalah dalam penelitian ini yaitu:

1. Bagaimana persepsi masyarakat terhadap bank syariah di Kabupaten Polewali Mandar?

2. Bagaimana pengaruh persepsi atas perbankan syariah terhadap preferensi masyarakat pada bank syariah di Kabupaten Polewali Mandar?

\subsection{Tujuan Penelitian}

Tujuan penelitian ini yaitu:

1. Untuk mengetahui persepsi masyarakat terhadap bank syariah di kabupaten Polewali Mandar.

2. Untuk mengetahui pengaruh persepsi terhadap preferensi masyarakat atas perbankan syariah di Kabupaten Polewali Mandar.

\subsection{Manfaat Penelitian}

Manfaat penelitian ini yaitu:

1. Bagi peneliti selanjutnya, hasil penelitian ini diharapkan dapat digunakan sebagai bahan rujukan untuk peneliti selanjutnya yang akan meneliti yang terkait bidang perbankan syariah.

2. Bagi Mahasiswa, hasil penelitian ini dapat digunakan sebagai pengayaan untuk bahan ajar khususnya dalam mata kuliah Ekonomi Syariah, Perbankan Syariah dan Akuntansi Syariah. Selain itu penelitian ini akan menghasilkan artikel ilmiah yang diterbitkan dalam prosiding nasional yang dapat dijadikan referensi bagi mahasiswa, khususnya di Universitas Sulawesi Barat.

3. Bagi Masyarakat, penelitian ini berkontribusi memberikan informasi kepada masyarakat akan keberadaan bank syariah sebagai salah satu alternatif lembaga keuangan yang dapat dimanfaatkan oleh masyarakat.

4. Bagi Pemerintah, hasil penelitian ini dapat dijadikan dasar pengembangan perbankan syariah bagi institusi yang berwenang misalnya Otoritas Jasa Keuangan ataupun Bank Indonesia di Provinsi Sulawesi Barat.

5. Bagi Industri Perbankan Syariah, hasil penelitian ini dapat menjadi masukan bagi bank syariah di Kabupaten Polewali Mandar dalam melaksanakan kegiatan pemasarannya agar dapat menarik minat masayarakat untuk memanfaatkan produk-produk bank syariah.

\section{BAHAN DAN METODE}

\subsection{Desain Penelitian}

Penelitian ini dilakukan untuk mengetahui bagaimana persepsi masyarakat pada bank syariah serta pengaruh persepsi tersebut terhadap preferensi masyarakat pada bank syariah di Kabupaten Polewali Mandar.Penelitian ini menggunakan pendekatan deskriptif kuantitatif.

\subsection{Tempat dan Waktu Penelitian}

Penelitian ini dilaksanakan di Kabupaten Polewali Mandar khususnya di kota Polewali dan Wonomulyo. Kedua kota tersebut di pilih dikarenakan dikedua kota/kecamatan tersebut telah berdiri bank syariah, yaitu Bank Syariah Mandiri (BSM), Bank Muamalat, dan BNI Syariah. Waktu penelitian dilaksanakan kurang lebih 1 tahun selama tahun 2017.

\subsection{Populasi dan Sampel}

Populasi penelitian ini meliputi masyarakat di dua kota di wilayah Kabupaten Polewali Mandar, dengan kriteria bahwa pada masing-masing daerah tersebut beroperasi kedua tipe bank (bank konvensional dan bank syariah), yaitu : Kota Polewali dan Kota Wonomulyo. Peneliti menentukan jumlah sampel yang diambil adalah sebanyak 125 responden. Sampel penelitian tersebut akan dibagi menjadi empat cluster : yaitu nasabah bank konvensional (25 orang), nasabah bank syariah (25 orang), nasabah bank syariah dan konvensional (25 orang), dan masyarakat umum (50 orang).

\subsection{Metode dan Analisis Data}

Penelitian ini menganalisis data menggunakan analisis deskriptif kuantitatif. Analisis deskriptif diperlukan guna untuk menjelaskan atau menjawab masalah yang pertama, tentang bagaimana persepsi masyarakat terhadap perbankan syariah di Kabupaten Polewali Mandar. Sedangkan metode kuantitatif, diperlukan untuk menjawab masalah kedua, tentang bagaimana pengaruh persepsi atas 
perbankan syariah terhadap preferensi masyarakat pada bank syariah di Kabupaten Polewali Mandar.Pada metode kuantitatif, penelitian ini menggunakan analisis regresi linier sederhana (Simple Linier Regression Analysis) antara persepsi (variabel independent) dengan preferensi (variabel dependent).

\section{HASIL DAN PEMBAHASAN}

\subsection{Analisis Data}

\section{Deskripsi Responden}

Data dalam penelitian ini diperoleh dengan cara menyebarkan kuesioner kepada 125 orang responden yang berada di Wilayah Kabupaten Polewali khususnya di Kecamatan Wonomulyo dan Kota Polewali. Adapun tingkat pengembalian kuisioner sebagai berikut:

Tabel 2. Tingkat Pengembalian Kuesioner

\begin{tabular}{clccc}
\hline No & Responden & Disebar & Kembali & Tidak kembali \\
\hline 1 & Nasabah Bank Syariah & 25 & 25 & 0 \\
2 & Nasabah Bank Konvensional & 25 & 20 & 5 \\
3 & Nasabah Bank Syariah \& Konvensional & 25 & 21 & 4 \\
4 & Masyarakat Umum & 50 & 50 & 0 \\
& Total & $\mathbf{1 2 5}$ & $\mathbf{1 1 6}$ & $\mathbf{9}$ \\
\hline
\end{tabular}

Sumber: Diolah,2017

Jumlah kuisioner yang disebarkan adalah 125, kuisioner yang kembali dan dapat diolah 116 . Adapun kuisioner yang tidak kembali dikarenakan ada beberapa masyarakat yang ketika diminta kuisionernya, mengatakan hilang dan rusak. Tingkat pengembalian kuisioner adalah $92 \%$. Adapun karakteristik responden yaitu sebagai berikut:

- 53 orang berjenis kelamin laki-laki atau $46 \%$ dan 63 orang perempuan atau $54 \%$.

- $97 \%$ beragama Islam dan sisanya $3 \%$ beragama Kristen.

- Usia responden yang paling dominan adalah antara usia 21-30 tahun sebanyak 43 orang atau $37 \%$ selanjutnya antara usia $31-40$ tahun sebanyak 40 orang atau $24 \%$, kemudian disusul usia 41-50 sebanyak 26 orang atau $22 \%$ dan terakhir yang berusia di atas 51 tahun sebanyak 7 orang atau $6 \%$.

- Pendidikan terakhir responden didominasi oleh tingkat SMA/SMK/Sederajat sebanyak 53 orang atau $46 \%$ disusul oleh pendidikan S1 sebanyak 49 orang atau $42 \%$ dan pendidikan Diploma sebanyak 10 orang atau $9 \%$ serta pendidikan S2 sebanyak 4 orang atau $4 \%$.

- Pekerjaan yang dilakukan oleh responden didominasi oleh PNS (Pegawai Negeri Sipil) yaitu sebanyak 40 orang atau sebanyak $34 \%$ kemudian disusul oleh responden yang bekerja sebagai pengusaha/wiraswasta sebanyak 31 orang atau $27 \%$, dan responden yang bekerja pada bidnag lainnya yang tidak disebutkan dalam kuisioner sebanyak 23 orang atau $20 \%$, kemudian sebagai pegawai swasta sebanyak 13 orang atau $11 \%$ serta sebagai ibu rumah tangga masing-masing sebanyak 9 orang atau $8 \%$.

Peneliti dalam penyebaran kuisionernya juga mengajukan beberapa pertanyaan kepada responden untuk mengetahui tingkat pengetahuan responden tentang bank syariah, adapun hasil jawaban yang diperoleh sebagai berikut:

1. "Apakah responden pernah mendengar atau mengetahui tentang Bank Syariah?" Berdasarkan hasil kuisioner diketahui bahwa sebagian besar responden mengetahui atau pernah mendengar tentang keberadaan bank syariah yaitu sebanyak 103 orang atau $89 \%$ sementara yang tidak mengetahui atau tidak pernah mendengar tentang keberadaan bank syariah yaitu sebanyak 13 orang atau hanya $11 \%$ saja.

2. "Melalui media apakah responden pernah mengetahui tentang Bank Syariah?"

Media informasi utama yang menjadi sumber pengetahuan responden tentang bank syariah yaitu melalui informasi dari teman/kerabat yaitu sebanyak 39 atau $38 \%$. Selanjutnya responden juga mengetahui tentang keberadaan Bank Syariah melalui media elektronik yaitu sebanyak 26 atau $25 \%$ dan melalui sumber informasi lainnya sebanyak 22 atau $21 \%$ dan terkahir informasi diperoleh responden melalui media cetak yaitu sebanyak 16 atau $16 \%$.

3. "Apakah responden pernah/sedang menjadi nasabah Bank Syariah?"

Dari 116 orang responden hanya $41 \%$ yaitu sebanyak 48 orang yang telah menjadi nasabah dari bank syariah. Sementara itu sebagian besar responden yaitu sebanyak 68 atau $59 \%$ belum atau tidak menjadi nasabah bank syariah. 


\section{4. "Apakah responden pernah/sedang menjadi nasabah Bank Konvensional?"}

Sebagian besar responden yakni sebanyak 99 orang atau $85 \%$ adalah sebagai nasabah bank konvensional semnetara sisanya yakni $15 \%$ yang tidak menjadi nasabah Bank Konvensional.

\section{Analisis Deskriptif Variabel Penelitian}

\section{1) Tanggapan Responden Terhadap Variabel $X$ (Persepsi)}

Pernyataan $1 \& 2$ kuisioner penelitian yang diajukan kepada responden terkait pengetahuan masyarakat tentang dasar keberadaan bank syariah yakni adanya fatwa MUI tentang bunga bank yang dinyatakan haram karena termasuk riba dan pemahaman tentang sistem bunga yang dijalankan pada bank konvensional termasuk kategori riba sehingga bertentangan dengan syariat Islam. Adapun hasilnya diperoleh bahwa sebesar $41 \%$ responden menjawab Netral, $28 \%$ menjawab Setuju, 16\% menjawab Tidak Setuju dan sisanya masing-masing 12\% menjawab Sangat Setuju serta 3\% menjawab Sangat Tidak Setuju. Dan untuk pernyataan 2, sebesar 39\% responden menjawab Netral, masing-masing 29\% responden menjawab Setuju, dan 19\% menjawab Tidak Setuju, sementara 12\% menjawab Sangat Setuju serta 1\% menjawab Sangat Tidak Setuju. Hal ini menunjukkan sebagian besar responden menunjukkan sifat netral/ragu-ragu terkait pemahaman mendasar terkait keberadaan bank syariah yang menjalankan prinsip syariat Islam yakni tidak diperkenankannya sistem bunga dalam Islam dikarenakan termasuk kategori riba.

Selanjutnya pernyataan $3 \& 4$ terkait persepsi masyarakat tentang bank syariah sebagai bank yang menjalankan sistemnya sesuai prinsip Syariat Islam serta prinsip bagi hasil yang diterapkan bank syariah yang lebih berkeadilan dibandingkan sistem bunga. Untuk pernyataan 3 sebesar $48 \%$ responden menjawab Setuju, 26\% menjawab Netral, 25\% menjawab Sangat Setuju, serta 1\% menjawab Sangat Tidak Setuju. Dan untuk pernyataan 4, sebesar $47 \%$ responden menjawab Setuju, 28\% menjawab Sangat Setuju, 22\% menjawab Netral, 3\% menjawab Tidak Setuju dan sisaya 1\% menjawab Sangat Tidak Setuju. Berdasarkan komposisi jawaban tersebut dapat diketahui bahwa hampir sebagian besar responden menyetujui keberadaan bank syariah sebagai bank yang menjalankan prinsip syariah dengan sistem bagi hasil yang berbeda dengan sistem bunga yang dijalankan oleh bank konvensional. Akan tetapi masih terdapat cukup besar responden yang juga bersifat netral atau ragu-ragu.

Pernyataan $5 \& 6$ terkait pernyataan yang menjelaskan beberapa paradigma yang salah yang saat ini masih berkembang, yakni bank syariah bukanlah bank khusus bagi orang Islam dikarenakan prinsip syariah yang bersifat universal dan pemikiran bahwa pada dasarnya prinsip atau sistem bank syariah sama saja dengan bank konvensional adalah tidak benar.Untuk pernyataan 5 sebagian besar responden menjawab Setuju yakni sebesar $53 \%$, diikuti oleh jawaban Netral sebesar $22 \%, 21 \%$ responden menjawab Sangat Setuju, dan 3\% responden menjawab Tidak setuju serta sisanya 1\% menjawab Sangat Tidak Setuju. Pernyataan 6, sebesar 36\% responden menjawab Setuju, diikuti oleh jawaban Netral sebesar 32\%, kemudian sebesar 19\% responden menjawab Sangat Setuju, 9\% menjawab Tidak Setuju dan terakhir $6 \%$ menjawab Sangat Tidak Setuju. Hasil jawaban responden ini menunjukkan bahwa untuk pernyataan 5 responden setuju bahwa Bank Syariah tidak diperuntukkan hanya bagi umat Islam saja. Namun di sisi lain untuk pernyataan 6 , responden belum keseluruhan menyetujui bahwa bank syariah berbeda dengan bank konvensional dalam menjalankan prinsip usahanya hal ini terlihat dari belum mayoritasnya jawaban setuju dan masih cukup besar jawaban netral/ragu-ragu.

\section{2) Tanggapan Responden Terhadap Variabel Y (Preferensi)}

Berdasarkan kuisioner yang diajukan kepada responden, pernyataan 1, 2 dan 3 terkait pemilihan masyarakat terhadap bank syariah dikarenakan pemahamannya tentang perbedaan riba dan sistem bagi hasil serta ketaatannya sebagai umat Muslim (bagi yang beragam Islam khususnya) terhadap syariat Agama Islam. Pada pernyataan 1 responden diberikan pernyataan "Saya ingin atau memilih menjadi nasabah bank syariah dikarenakan pemahaman saya tentang riba", sementara itu pernyataan 2 yaitu "Saya menyukai sistem bagi hasil pada Bank Syariah dibandingkan dengan sistem bunga pada Bank Konvensional/Bank Umum." Sementara itu pernyataan 3 "Saya memilih Bank Syariah diakrenakan ketaatan saya pada syariat agama". Untuk pernyataan 1 sebesar $43 \%$ responden menjawab Netral, 34\% menjawab Setuju, 11\% menjawab Sangat Setuju dan sisanya 10\% menjawab Tidak Setuju serta 2\% menjawab Sangat Tidak Setuju. Dan untuk pernyataan 2, sebesar $40 \%$ responden menjawab Setuju, 36\% responden menjawab Netral, Sangat Setuju sebesar 17\%, sementara 5\% menjawab Tidak Setuju serta 2\% menjawab Sangat Tidak Setuju. Sementara itu, untuk pernyataan 3 sebagian besar responden yakni sebesar $47 \%$ menjawab Netral, 34\% menjawab Setuju, $11 \%$ menjawab Sangat Setuju, dan 6\% menjawab Tidak Setuju, serta 2\% menjawab Sangat Tidak Setuju. Hal ini menunjukkan sebagian besar responden menunjukkan sikap netral atau keragu- 
raguannya terkait pemilihan atau keinginan untuk memilih menjadi nasabah bank syariah dikarenakan alasan pemahamannya akan hal-hal mendasar yang menjadi alasan keberadaan bank syariah yaitu terkait sistem riba yang tidak diperbolehkan dalam Islam, serta ketaatan terhadap aturan agama khususnya bagi umat Muslim. Akan tetapi untuk pernyataan terkait kelebihan sistem bagi hasil dibandingkan dengan sistem bunga yang jadi prinsip utama bagi perbankan syariah menjadi alasan yang banyak dipilih oleh responden.

Pernyataan 4, 5 dan 6 terkait preferensi masyarakat terhadap bank syariah didasarkan pada produk, pelayanan, fsasiltas serta lokasi. Adapun pernyataannya sebagai berikut: Pernyataan 4 "Saya berpikir produk perbankan syariah lebih baik dan menguntungkan", pernyataan 5 "Saya memilih Bank Syariah dikarenakan pelayanan yang ramah dan fasilitasnya yang lengkap", serta pernyataan 6 "Saya memilih Bank Syariah diakrenakan lokasinya yang terjangkau dengan tempat tinggal saya". Adapun hasil tanggapan responden adalah sebagai berikut: untuk pernyataan 4, sebagian besar responden yaitu sebesar 46\% menjawab Netral, 34\% menjawab Setuju, 13\% menjawab Sangat Setuju, 6\% menjawab Tidak Setuju, dan 1\% menjawab Sangat Tidak Setuju. Untuk pernyataan 5 sebagian besar responden menjawab Netral yakni sebesar $47 \%$, diikuti oleh jawaban Setuju sebesar $30 \%$, $17 \%$ responden menjawab Sangat Setuju, dan 3\% responden menjawab Tidak Setuju serta sisanya $2 \%$ menjawab Sangat Tidak Setuju. Pernyataan 6, sebesar 49\% responden menjawab Netral, diikuti oleh jawaban Setuju sebesar 25\%, kemudian sebesar 13\% responden menjawab Sangat Setuju dan 9\% menjawab Tidak Setuju, serta sisanya sebesar $4 \%$ menjawab Sangat Tidak Setuju. Berdasarkan komposisi jawaban tersebut dapat diketahui bahwa hampir sebagian besar responden memilih jawaban Netral/Ragu-Ragu. Hal ini menunjukkan bahwa dari sisi preferensinya terhadap bank syariah, responden belum menjadikan produk,pelayanan,fasilitas serta lokasi yang terjangkau sebagai dasar pemilihannya terhadap perbankan syariah.

\section{Pengujian Hipotesis}

1) Koefisien Determinasi

Koefisien determinasi adalah nilai yang menunjukkan proporsi pengaruh variabel independen yang dapat menjelaskan variabel dependen. Berdasarkan hasil pengujian SPSS didapatkan nilai koefisien determinasi sebagai berikut:

Tabel 3. Koefisien Determinasi

\begin{tabular}{|l|r|r|r|r|r|}
\hline Model & \multicolumn{1}{|c|}{$\mathrm{R}$} & R Square & \multicolumn{1}{c|}{$\begin{array}{c}\text { Adjusted R } \\
\text { Square }\end{array}$} & $\begin{array}{c}\text { Std. Error of } \\
\text { the Estimate }\end{array}$ & Durbin-Watson \\
\hline 1 & $.505^{\mathrm{a}}$ & .255 & .249 & 3.549 & 1.755 \\
\hline
\end{tabular}

a. Predictors: (Constant), Persepsi Terhadap Bank Syariah

b. Dependent Variable: Preferensi Masyarakat Pada Bank Syariah

Dari tabel di atas dapat diketahui bahwa $\mathrm{R}^{2}$ sebesar 0,255 , nilai ini menunjukkan bahwa variabel independen (persepsi terhadap bank syariah) hanya mampu menjelaskan variabel dependen (preferensi masyarakat pada bank syariah) sebesar $25,5 \%$ dan sisanya sebesar $74,5 \%$ dijelaskan oleh variable lain yang tidak diteliti dalam penelitian ini.

\section{2) Uji T (Pengaruh Parsial)}

Pengujian secara parsial untuk mengetahui apakah ada pengaruh antara persepsi masyarakat terhadap preferensi masyrakat dalam memilih bank syariah. Adapun hasil pengujian SPSS didapatkan nilai sebagai berikut:

Tabel 4. Hasil Uji T

\begin{tabular}{|c|c|c|c|c|c|c|}
\hline \multirow{2}{*}{\multicolumn{2}{|c|}{ Model }} & \multicolumn{2}{|c|}{ Unstandardized Coefficients } & \multirow{2}{*}{\begin{tabular}{|c|}
$\begin{array}{c}\text { Standardized } \\
\text { Coefficients }\end{array}$ \\
Beta \\
\end{tabular}} & \multirow[b]{2}{*}{$\mathrm{t}$} & \multirow[b]{2}{*}{ Sig. } \\
\hline & & $B$ & Std. Error & & & \\
\hline \multirow[t]{2}{*}{1} & (Constant) & 8.169 & 2.077 & & 3.933 & .000 \\
\hline & $\begin{array}{l}\text { Persepsi Terhadap Bank } \\
\text { Syariah }\end{array}$ & .582 & .093 & .505 & 6.248 & .000 \\
\hline
\end{tabular}

a. Dependent Variable: Preferensi Masyarakat Pada Bank Syariah 
Berdasarkan tabel 4 di atas diperoleh nilai signifikansi untuk variabel $X$ (persepsi masyarakat) sebesar 0,000 . Ketentuan pengambilan keputusan hipotesis diterima atau ditolak didasarkan pada besarnya nilai signifikansi. Jika signifikansi lebih kecil atau sama dengan $0.05(<0.05)$, maka hipotesis diterima dan sebaliknya. Hasil penelitian diperoleh nilai signifikansi sebesar $0,000(<0.05)$, maka disimpulkan bahwa persepsi masyarakat pada bank syariah berpengaruh terhadap preferensi masyarakat atas bank syariah.

\subsection{Pembahasan Hasil Penelitian}

Perkembangan perbankan syariah apabila dibandingkan dengan perbankan konvensional/umum masih sangat jauh baik dari sisi jumlah nasabah, maupun dari sisi penghimpunan dan penyaluran dana. Hal ini juga terjadi di wilayah Sulawesi Barat khususnya di Kabupaten Polewali Mandar. Apabila dilihat dari jumlah Bank Syariah yang beroperasi di wilayah Kabupaten Polewali Mandar,saat ini hanya terdapat 3 bank syariah yaitu 2 bank syariah di wilayah Wonomulyo dan 1 bank syariah di wilayah Polewali. Tidak hanya dari sisi keberadaan bank syariahnya saja, persepsi masyarakat juga menjadi satu hal yang menjadi alasan belum berkembangnya perbankan syariah di wilayah Polewali Mandar.

Berdasarkan hasil analisis dari kuisioner yang disebarkan kepada 116 responden, menunjukkan bahwa sebagian besar responden secara umum telah mengetahui tentang keberadaan perbankan syariah di wilayah Polewali Mandar akan tetapi dari $89 \%$ responden yang mengetahui tentang perbankan syariah, hanya sebesar $41 \%$ yang kemudian menjadi nasabah dari bank syariah tersebut. Sebagian besar dari responden justru adalah nasabah dari perbankan konvensional dan terdapat beberapa nasabah yang juga menjadi nasabah bank konvensional dan bank syariah sekaligus.

Masih kurangnya minat masyarakat menjadi nasabah bank syariah dapat dilihat dari persepsi mereka terhadap perbankan syariah itu sendiri. Sebagaimana hasil deskriptif variabel yang telah dijelaskan sebelumnya bahwa sebagian besar jawaban responden yang menjawab netral/ragu-ragu menunjukkan kurangnya pemahaman mereka terhadap perbankan syariah. Adapun pemahaman yang dimaksud terkait hal-hal mendasar yang menjadi alasan terbentuknya perbankan syariah sebagai solusi atas kebutuhan masyarakat yang kemudian direspon industri perbankan untuk menghadirkan sistem perbankan yang sesuai dengan syariat Islam yang jauh dari sistem riba yaitu bunga sebagaimana yang saat ini diterapkan di perbankan konvensional. Persepsi masyarakat terutama didominasi oleh ketidak tahuan mereka atau ketidak pahaman mereka tentang riba yang bahkan telah difatwakan oleh MUI yang mengkategorikan sistem riba adalah haram.

Sementara itu, berdasarkan hasil analisis deskriptif menunjukkan bahwa masyarakat pada umumnya telah mengetahui bahwa prinsip yang dijalankan perbankan syariah dengan sistem bagi hasilnya lebih baik daripada sistem bunga yang dijalankan oleh perbankan konvensional. Sistem bagi hasil dianggap lebih berkeadilan karena umumnya masyarakat akan merasa terbebani oleh beban bunga yang cukup besar yang umumnya dianut oleh sistem perbankan konvensional. Berdasarkan hasil analisis deskriptif variabel, dapat diketahui pula bahwa sebagian besar masyarakat juga memberikan persepsi yang baik terkait keberadaan bank syariah yang tidak hanya diperuntukkan bagi umat Muslim serta perbedaan mendasar antara bank syariah dan bank konvensional yang menunjukkan pengakuan masyarakat tentang kemurnian prinsip syariah yang dijalankan oleh perbankan syariah.

Walaupun secara umum persepsi masyarakat sebagian besar menunjukkan hasil yang baik akan tetapi dari sisi preferensi, sebagian besar masyarakat berdasarkan hasil kuisioner belum sepenuhnya menempatkan pilihannya pada perbankan syariah. Hal ini secara umum menunjukkan bahwa walaupun masyarakat telah mengakui akan tetapi tidak serta merta hal tersebut mendorong masyarakat untuk memilih bank syariah.

Berdasarkan hasil analisis deskriptif, yang menjelaskan hasil tanggapan responden terhadap variabel preferensi menunjukkan bahwa sebagian besar jawaban responden didominasi oleh jawaban netral/ragu-ragu. Keraguan tersebut menunjukkan kurangnya minat mereka atau belum adanya keinginan yang kuat untuk memilih atau menjadi nasabah dari perbankan syariah.

Selain hasil kuisioner, peneliti juga memberikan pertanyaan terbuka kepada responden tentang bagaimana pendapat mereka terhadap perbakan syariah. Dari 116 responden, sebanyak 48 $(41 \%)$ responden memberikan tanggapannya. Adapun tanggapan responden secara umum dapat dipilah menjadi 4 hal sebagai berikut:

1. Masih perlu adanya sosialisasi tentang bank syariah karena masyarakat masih kurang paham tentang bank syariah khususnya terkait produk dan prinsip-prinsipnya.

2. Perlu adanya peningkatan jumlah bank syariah di wilayah Kabupaten Polewali Mandar agar memudahkan akses masyarakat terhadap perbankan syariah.

3. Peningkatan pelayanan,produk dan fasilitas agar dapat bersaing dengan perbankan konvensional. 
4. Mendukung keberadaan perbankan syariah dengan mempertahankan serta meningkatkan sistem perbankan yang benar-benar sesuai syariat Islam.

\section{KESIMPULAN}

Adapun kesimpulan penelitian ini yaitu:

1. Persepsi masyarakat atas bank syariah menunjukkan bahwa sebagian besar masyarakat menyetujui keberadaan bank syariah yang menerapkan prinsip bagi hasil yang sesuai dengan syariat Islam serta keberadaan bank syariah yang berbeda dari sistem perbankan konvensional. Akan tetapi masih terdapat sikap netral/keragu-raguan dari masyarakat terhadap pemahaman akan riba yang difatwakan haram oleh MUI serta sistem bunga yang termasuk kategori riba yang dijalankan oleh perbankan konvensional.

2. Persepsi masyarakat terhadap bank syariah berpengaruh secara positif dan signifikan terhadap preferensi masyarakat atas bank syariah.

\section{DAFTAR PUSTAKA}

Ary Permatadeny, Nevita dan Arifin, Zainal. 2015. Perilaku,Karakteristik,Persepsi Masyarakat Terhadap Bank Syariah di Eks Karasidenan Kediri. Jurnal Nusantara of Research. 2:151.

Bank Indonesia Dengan Lembaga Penelitian IPB. 2000. Penelitian potensi Prefensi, Dan Perilaku Masyarakat Terhadap Bank Syari'ah Di Jawa Barat. BI Dan Lembaga Penelitian IPB. Bogor.

Meidar F.M. 2007. Kamus Lengkap Exclusive Inggris - Indonesia. Eskamedia. Jakarta.

Muhammad, 2002. Manajemen Bank Syariah. UPP AMP YKPN. Yogyakarta.

Philip Kotler, Kevin Lane keller,2009. Manajemen Pemasaran. Erlangga. Jakarta.

Prihasta, Lailatus Sembrada. 2015. Persepsi,Perilaku dan Preferensi Masyarakat Tulungagung Terhadap Bank Muamalat.Tesis.Fakultas Ekonomi dan Bisnis Islam IAIN, TulungAgung.

Robbani,Shofa. 2013. Analisis Pemahaman Nasabah BNI Syariah Tentang Ke'Syariah'an BNI Syariah. Jurnal Ekonomi Islam. 2(1):58.

Sugiyono. 2008. Metode Penelitian Kuantitatif Kualitatif dan R\&D. Alfabeta. Bandung.

Sutisna. 2001.Perilaku Konsumen dan Komunikasi Pemasaran. PT Remaja Rosdakarya. Bandung.

Undang-Undang Republik Indonesia Nomor 21 Tahun 2008 tentang Perbankan Syariah. 2008. Kementrian Hukum dan HAM Republik Indonesia. Jakarta.

www.bi.go.id

www.ojk.go.id

www.syariahmandiri.co.id 